\title{
Phytochemical Analysis and Antibacterial Activities of Sidr Leaf Extract (Ziziphus spina-christi) against Pathogenic Bacteria in Aquaculture
}

\author{
Sarjito $^{1 *}$, Lukita Purnamayati ${ }^{2}$, Putut Har Riyadi ${ }^{2}$, Desrina ${ }^{1}$ and Slamet Budi \\ Prayitno ${ }^{1}$
}

${ }^{1}$ Aquaculture Study Program, Department of Aquaculture, Faculty of Fisheries and Marine Sciences, Diponegoro University, Jl. Prof. H. Soedarto, SH Tembalang, Semarang, Central Java, Indonesia

${ }^{2}$ Fish Product Utilization Department, Faculty of Fisheries and Marine Sciences, Diponegoro University, Jl. Prof. H. Soedarto, SH Tembalang, Semarang 50275, Central Java, Indonesia

\begin{abstract}
The success rate of aquaculture is highly influenced by several factors, including optimum water quality, feed management, and microorganism control. Several microorganisms interfere with the quality of media and fish culture, i.e., fish growth. Aeromonas and Vibrio are the main pathogenic bacteria that disrupt fish growth and cause mortality. Sidr leaf (Ziziphus spina-christi) extract contains phytochemicals that have antibacterial properties. This study aimed to identify the phytochemical components and analyze the effect of Sidr leaf extract on the growth of aquaculture-based pathogenic bacteria. Sidr leaf extract was obtained using ethanol and tested via phytochemical analysis, chemical analysis, prediction of activity spectra for substances (PASS) examination, and inhibition capability against Aeromonas hydrophila, Aeromonas caviae, Aeromonas sobria, Pseudomonas putida, Pseudomonas aeruginosa, Streptococcus

ARTICLE INFO

Article history:

Received: 28 May 2021

Accepted: 7 September 2021

Published: 3 November 2021

DOI: https://doi.org/10.47836/pjtas.44.4.08

E-mail addresses:

sarjito@live.undip.ac.id (Sarjito)

lukita_anandito@yahoo.com (Lukita Purnamayati)

putut.riyadi@live.undip.ac.id (Putut Har Riyadi)

rinadesrina@yahoo.com (Desrina)

sbudiprayitno@gmail.com (Slamet Budi Prayitno)

*Corresponding author agalactiae, Vibrio vulnificus, Vibrio harveyi, Vibrio parahaemolyticus, and Vibrio alginolyticus. The results showed that Sidr leaf extract contained phytochemicals, namely, flavonoids, alkaloids, saponins, tannins, and steroids. Gas chromatographymass spectrometry analyses showed that the Sidr leaf extract contained 30 compounds with antiseborrheic effects. PASS analysis demonstrated that 15 compounds $(64.51 \%$ level) have potential as antibacterial, with
\end{abstract}


a probability activity value of more than 0.300 . The inhibition test showed that the Sidr leaf extract exhibited moderateto-strong inhibition against pathogenic bacterial growth, except for $V$. vulnificus, for which it produced a weak inhibition. The results indicate that Sidr leaf extract can be used as a natural herb to control bacterial pathogens in fish cultivation.

Keywords: Aeromonas, antibacterial, aquaculture, Sidr leaf extract, Vibrio

\section{INTRODUCTION}

Aquaculture plays an essential role in the Indonesian economy, and its production increases annually. Fish production from the marine culture in 2016 reached 9,773,055 tons and increased to $9,808,494$ tons in 2017, and it is projected to reach 12 million tons in 2023 (Statistics Indonesia [BPS], 2020). This target projection was launched to meet both domestic and export needs. Tran et al. (2017) stated that there is a continuous increase in international market demand. Therefore, considerable effort should be exerted to achieve production and fulfill food safety and food security.

One of the efforts to increase aquaculture fish production is to avoid antibiotics while improving fish culture and survival rate. Feeds with good nutrition can also provide well-maintained fish growth (Prabu et al., 2017). Microorganisms in fish farming grow naturally and, in several cases, are intentionally added to maintain water quality and fish survival. However, several organisms interfere with fish growth through infection and cause mortality to cultured fish (Bentzon-Tilia et al., 2016). The pathogenic bacteria that frequently disrupt fish culture are generally members of Aeromonas and Vibrio. In Aeromonas, fish infected include A. sobria, A. caviae, and A. hydrophila, whereas those from vibrios comprise $V$. vulnificus and $V$. harveyi (Atujona et al., 2018; Monteiro et al., 2018; Pan et al., 2017). Several antibiotics, including tetracycline, oxolinic acid, and florfenicol, have suppressed pathogenic bacteria. However, these antibiotics leave a residue, and certain fish are resistant to antibiotics. The improper utilization of antibiotics in aquaculture can result in multidrug-resistant bacteria in media culture (Igbinosa et al., 2017). Aeromonas isolated from fish farming in Denmark has shown $69 \%$ resistance to oxytetracycline, $20 \%$ resistance to oxolinic acid, and resistance to florfenicol for several isolates. Antibiotic-resistant bacteria can spread and infect humans (Monteiro et al., 2018). Therefore, minimizing the use of antibiotics is needed to prevent the development of resistant bacteria. The addition of microalgae (Spirulina platensis and Chorella vulgaris) to aquafeed was reported by Joshua and Zulperi (2020) to improve fish immunity. Other natural antibacterial sources have been used in conventional medicine, such as Ziziphus (Al-Mutairi et al., 2016), and may prove useful to preventing disease outbreaks and supporting sustainable aquaculture.

The Sidr plant (Ziziphus spina-christi) is a tropical plant that has been used as 
herbal medicine to treat fever, dandruff, eye diseases, and inflammation. The studies show that Sidr leaves have antibacterial properties as demonstrated by the ability to inhibit the growth of Escherichia coli, Klebsiella spp., Pseudomonas aeruginosa, and Salmonella sp. (A1-Mutairi et al., 2016). Ethanol- and methanol-derived Sidr leaf extracts can also inhibit the growth of various Gram-positive and Gram-negative bacteria (Khaleel et al., 2019; Temerk et al., 2017). These effects are due to the phytochemical contents of Sidr leaves, such as alkaloids, flavonoids, and saponins (Asgarpanah \& Haghighat, 2012). Sidr leaves also contain phenols with a lethal concentration $50\left(\mathrm{LC}_{50}\right)$ concentration of $21.40 \mu \mathrm{g} / \mathrm{mL}$. These serve as a source of antioxidants for pharmaceuticals (Khaleel et al., 2019). Based on their phytochemical content, Sidr leaves can be a source of natural antibiotics in aquaculture. Such a natural source would be beneficial because it can reduce antibiotic residues in cultured products and bacteria resistance in the aquaculture environment. This study aimed to determine the phytochemical compounds and the performance of Sidr leaf extract to control various bacterial pathogens in aquaculture in vitro.

\section{MATERIALS AND METHODS}

\section{Materials}

Dry Sidr leaves (Ziziphus spina-christi) were obtained from Sukoharjo District, Central Java, Indonesia. Aquatic pathogenic bacteria (A. hydrophila, A. caviae, A. sobria,
P. putida, $P$. aeruginosa, and $S$. agalactiae) were isolated from tilapia from Magelang, Central Java, Indonesia. Additionally, $V$. vulnificus, $V$. harveyi, V. parahaemolyticus, and $V$. alginolyticus were obtained from the Center for Brackish Water Cultivation Fisheries Jepara, Central Java, Indonesia. The bacteria were cultured on trypticase soy agar, tryptone soya broth, nutrient broth, and nutrient agar (Merck, Germany).

\section{Preparation of Sidr Leaf Extract}

Sidr leaf extract was prepared according to Al-Mutairi et al. (2016) with several modifications. A total of $200 \mathrm{~g}$ dried Sidr leaves were sieved using a 60-mesh sieve. The resulting Sidr leaf powder was then immersed in $96 \%$ ethanol at a ratio of $1: 10$ ( $\mathrm{vol} / \mathrm{vol})$ and then ultrasonicated for $1 \mathrm{hr}$. The powder was then macerated for $24 \mathrm{~h}$ and filtered using Whatman No. 1 filter paper with a vacuum pump to speed up the process. The aqueous filtered part was evaporated in a rotary evaporator at a temperature of $45^{\circ} \mathrm{C}-60^{\circ} \mathrm{C}$ for $2 \mathrm{hr}$ until the extract thickened. The extract was stored at $\pm 5^{\circ} \mathrm{C}$ for phytochemical and antibacterial tests.

\section{Phytochemical Analysis of Sidr Leaf Extract}

Phytochemical analysis was conducted to identify the compounds in Sidr leaf extract, including flavonoids, tannins, alkaloids, saponins, and steroids. The phytochemical procedure was performed according to Temerk et al. (2017). The flavonoid test 
was conducted by adding $1 \mathrm{~mL}$ of $10 \%$ sodium hydroxide $(\mathrm{NaOH})$ to a $3 \mathrm{~mL}$ extract. A yellow extract color exhibited the presence of flavonoids. The tannin test was conducted using one to two drops of $1 \%$ iron (III) chloride $\left(\mathrm{FeCl}_{3}\right)$ to $1 \mathrm{~mL}$ extract. A positive reaction showed a color change to green-black or dark-blue color. The alkaloid test was conducted by adding $1 \mathrm{~mL}$ of $1 \%$ hydrogen chloride $(\mathrm{HCl})$ to $3 \mathrm{~mL}$ extract in a test tube. The mixture was then heated for 20 min, chilled, and filtered. Two drops of Mayer's reagent were then added to $1 \mathrm{~mL}$ of extract. A thick residue indicated the presence of alkaloids. The saponin test was conducted by shaking a $2 \mathrm{~mL}$ aliquot in a test tube for $2 \mathrm{~min}$. A foam formation indicated a positive reaction. Finally, the steroid test was conducted by adding five drops of concentrated sulfuric acid $\left(\mathrm{H}_{2} \mathrm{SO}_{4}\right)$ to $1 \mathrm{~mL}$ extract in a test tube. The appearance of a red color indicated the presence of steroids.

\section{Chemical Component Analysis of Sidr Leaf Extract with Gas Chromatography-Mass Spectrometry (GC-MS)}

Phytochemical analysis with GC-MS was conducted according to Ads et al. (2017). A total of $1 \mu \mathrm{L}$ sample was injected into the GC-MS equipment (GC17A MSQP 5000 Shimadzu, Japan) using a TG-SQC column $15 \mathrm{MX}(0.25 \mathrm{~mm} \times 0.25 \mu \mathrm{m})$ at an injector temperature of $250^{\circ} \mathrm{C}$. The oven temperature was set to $50^{\circ} \mathrm{C}$ and increased to $150^{\circ} \mathrm{C}$ with an average increase of $7^{\circ} \mathrm{C} / \mathrm{min}$. Then, heating was continued until $250^{\circ} \mathrm{C}$ with an average rate of $5^{\circ} \mathrm{C} / \mathrm{min}$ and to $290^{\circ} \mathrm{C}$ with an average rate of $10^{\circ} \mathrm{C} / \mathrm{min}$. The extract was injected in split mode. The results were then matched with the mass spectra peaks in the Wiley library (Stein et al., 2011).

\section{Prediction of Activity Spectra for Substances (PASS)}

PASS analysis was conducted according to Parasuraman (2011) using the PASS web tool. The PASS web tool interprets active biological spectra with a two-dimensional structure and predicts probability to be active and probability to be inactive (Pa: $\mathrm{Pi}$ ) ratio. The research was conducted in two phases: (1) accessing the Pub Chem server (https:// pubchem.ncbi.nlm.nih.gov/) to obtain the canonical simplified molecular-input lineentry system (SMILES) information and (2) predicting the biological activity via PASS analysis using the website, http://www. way2drug.com/PASSOnline/index.php, by entering the canonical SMILES structure (Riyadi et al., 2020).

\section{Inhibition Test}

The inhibition test was conducted according to Motamedi et al. (2014) using the disk method. As much as $0.1 \mathrm{~mL}$ cultured bacteria with $10^{8} \mathrm{cfu} / \mathrm{mL}$ density were obtained and spread onto an agar plate. Sterilized 6-mm-diameter paper disks were immersed in various Sidr leaf extracts prepared using distilled water (100, 300, 500 , and $800 \mathrm{mg} / \mathrm{L}$ ) for $1 \mathrm{hr}$. Additionally, tetracycline $(10 \mathrm{mg} / \mathrm{L})$ was used as the positive control, and distilled water was 
used as the negative control. The paper disks were then placed onto inoculated pathogenic bacterial agar and incubated for 24-48 hr. The clear zone produced around the paper disk was measured as the inhibition zone. The test was conducted in triplicate at each extract concentration.
RESULTS AND DISCUSSION

\section{Phytochemistry of Sidr Leaf Extract and Their Properties}

The phytochemical screening tests (Figure 1) showed that the Sidr leaf extract contained secondary metabolite compounds, such as flavonoids, alkaloids, saponins, tannins, and steroids.
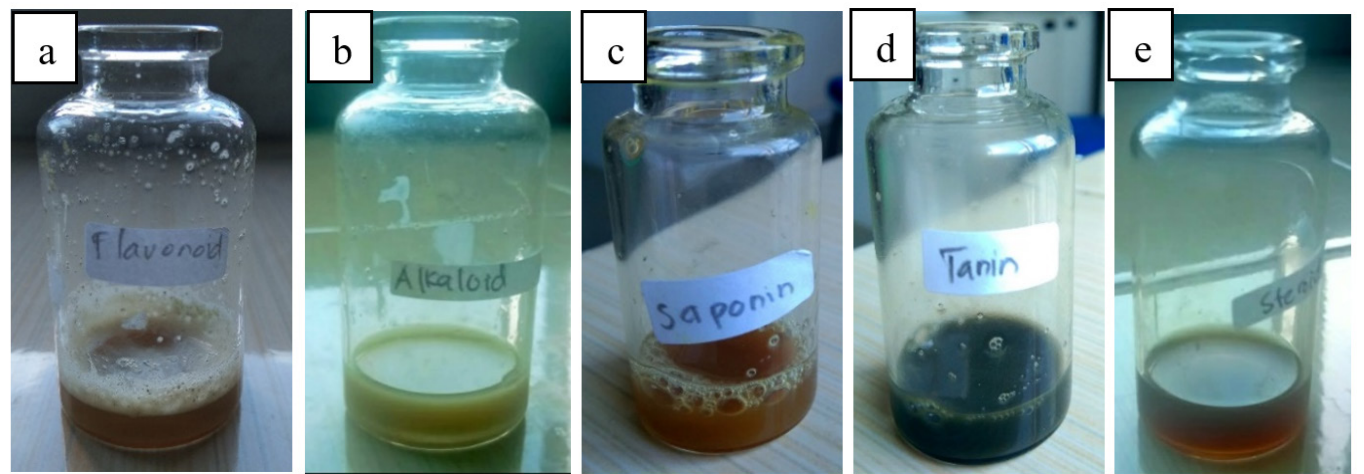

Figure 1. Phytochemicals contained in Sidr (Ziziphus spina-christi) leaf extract

Note. a) flavonoid, b) alkaloid, c) saponin, d) tannin, and e) steroid

Table 1

Phytochemicals identified in Sidr (Ziziphus spina-christi) leaf extract

\begin{tabular}{cccc}
\hline No. & Compound & Color & Result analysis \\
\hline 1. & Flavonoid & Yellow & + (Positive) \\
2. & Alkaloid & Thick sediment & + (Positive) \\
3. & Saponin & Bubble & + (Positive) \\
4. & Tannin & Blueish green color & + (Positive) \\
5. & Steroid & Red color & + (Positive) \\
6. & Triterpenoid & Brownish red & + (Positive) \\
\hline
\end{tabular}

Flavonoids, phenolic compounds, triterpenic acids, and polysaccharides have been reported as the major phytoconstituents of Zizyphus species (Soni \& Malik, 2021). However, various studies have reported different phytochemical contents in $Z$. spina-christi leaf extracts. According to Asgarpanah and Haghighat (2012), Sidr leaf phytochemical content consists of saponins, alkaloids, and flavonoids. 
Different results are shown by Ibrahim et al. (2015), who found alkaloids to be the significant phytochemical of Sidr leaf from Nigeria. Ermias et al. (2011) and Alhassan et al. (2019) found that steroid, flavonoid, tannin, lipid, anthraquinone, saponin, and alkaloid are present in $Z$. spina-christi leaf extracts. By contrast, Suliman and Mohammed (2018) found that the phytochemical components of Sidr leaf from Sudan do not contain steroids. Furthermore, Taghipour et al. (2020) stated that the ethanol extract of Iranian Sidr leaf contains alkaloids, tannins, saponins, and flavonoids. This variation in phytochemical content is likely due to differences in climate and environmental conditions where the plant grows. Environmental and climatic conditions, especially temperature, soil type, and age of the plant, affect herbs' chemical content and functional properties (Gull et al., 2012; Inbathamizh \& Padmini, 2013). Mbunde et al. (2018) also showed that the areas where herbs grow, such as the coast, highlands, and mountains with different soil types, cause differences in phytochemical content such as phenolics and flavonoids.
The phytochemical components of Sidr leaf extract (Table 1) can have antibacterial properties. For example, flavonoids have antibacterial, antioxidant, and antiinflammatory properties (Adamczak et al., 2020). Alkaloids possess antibacterial and antifungal properties. Saponins function as barriers against pathogenic bacteria, improve immunity, and have antibacterial, antioxidant, anticancer, and antidiabetic activities. Tannin is a compound that binds proteins and forms water-insoluble compounds. Tannins, as an antibacterial, bind proteins in the bacterial cell wall and coagulate the materials to inhibit bacterial growth (Dangoggo et al., 2012; Ravi et al., 2016). Steroids, consisting of cholesterol and ergosterol, are components of cell membranes. Fusidic acid is a steroid compound that can prevent Gram-positive and Gram-negative bacterial infections (Doğan et al., 2017).

\section{Sidr Leaf Compound Components and PASS Results}

Figure 2 and Table 2 describe the GC-MS analysis results on Sidr leaf compounds.

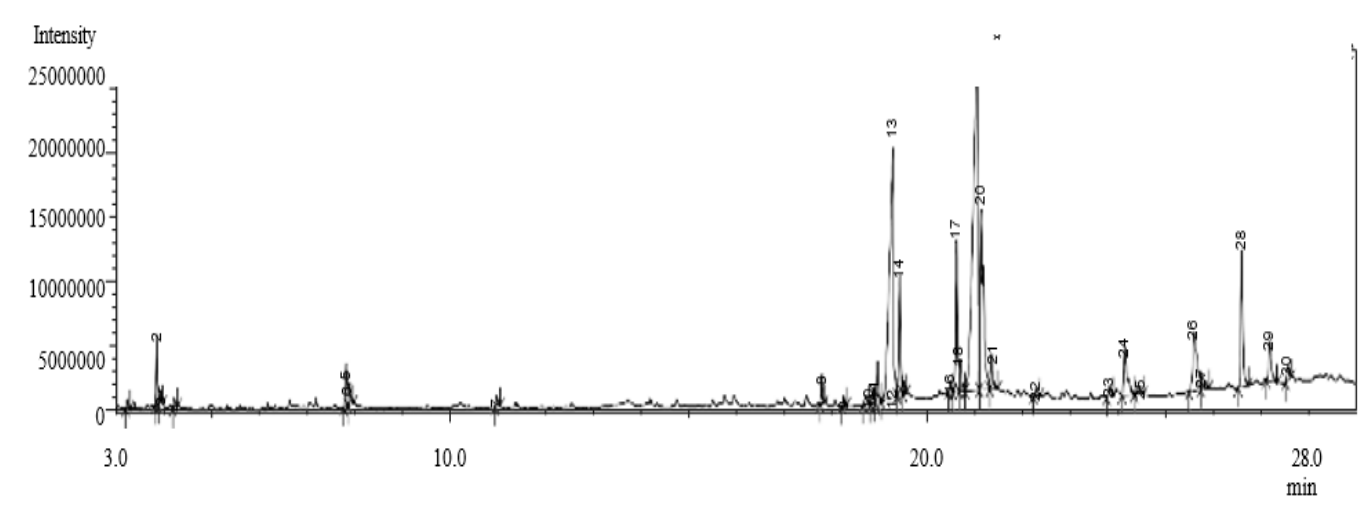

Figure 2. GC-MS chromatogram of the Sidr (Ziziphus spina-christi) leaf extract 
Antibacterial Properties of Sidr Leaf Extract in Aquaculture

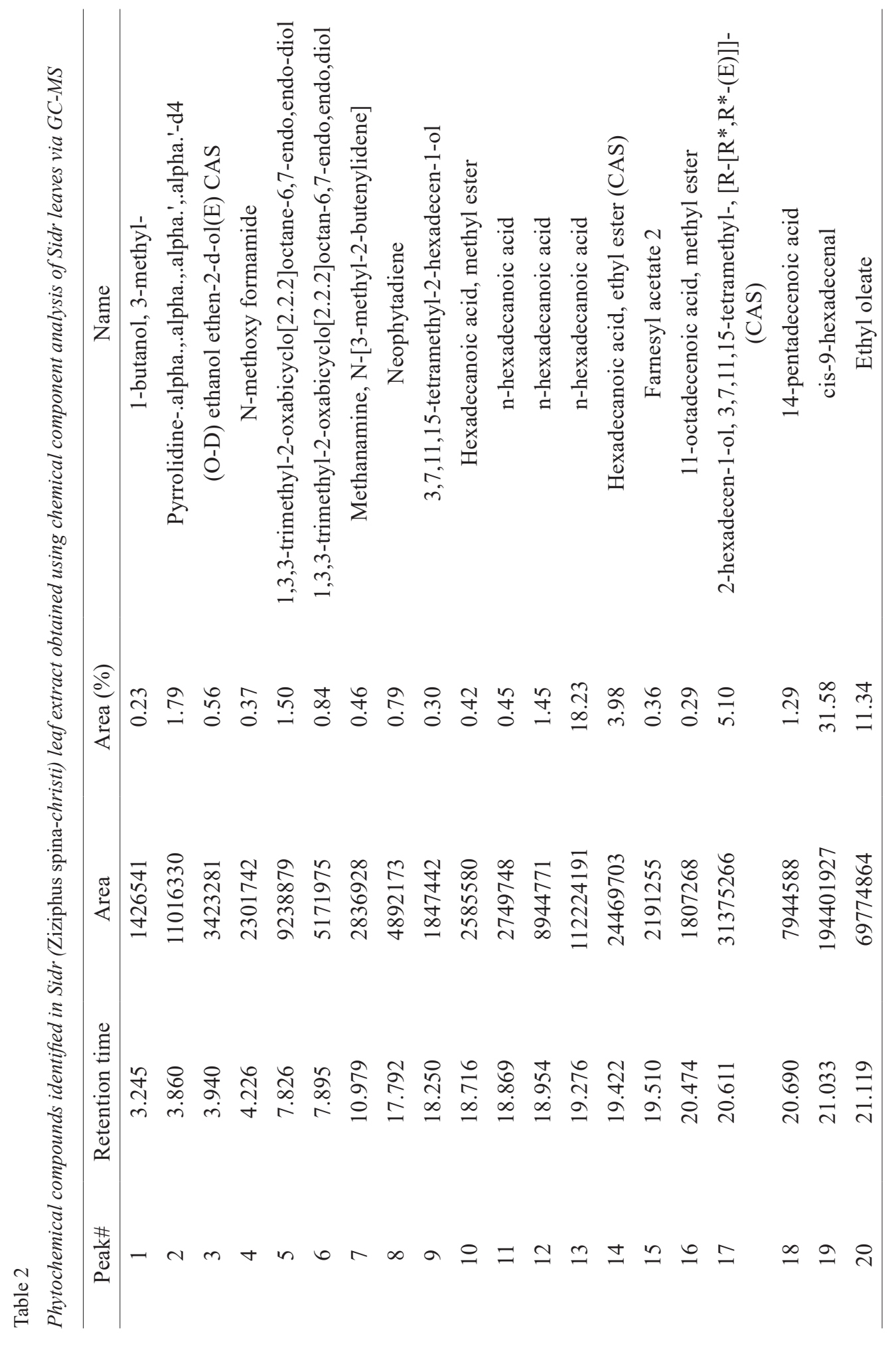

Pertanika J. Trop. Agric. Sci. 44 (4): 845 - 864 (2021) 


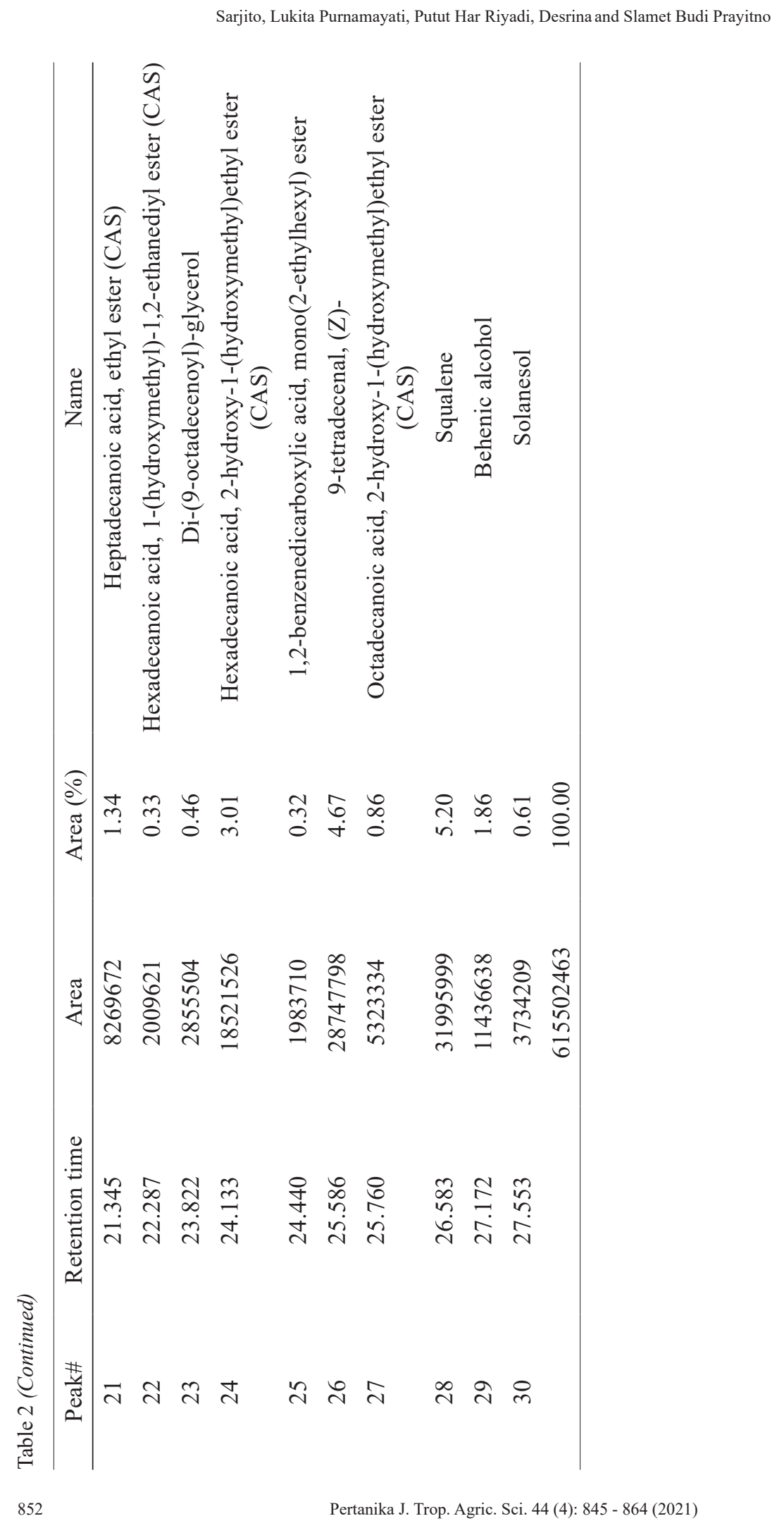


Based on the GC-MS analysis, the Sidr leaf extract contained 30 chemical compounds (Table 2). These 30 chemical compounds comprised the following: 1-butanol, 3-methyl; optical density (OD) ethanol; pyrrolidine; n-methoxy formamide; two kinds of 1,3,3-trimethyl-2-oxabicyclo [2.2.2] octane-6,7-endo, endo-diol; methenamine, $\mathrm{N}-[3$-methyl-2-butenylidene]; neophytadiene; 3,7,11,15-tetramethyl2-hexadecen-1-ol; hexadecanoic acid, methyl ester; three kinds of n-hexadecanoic acid; farnesyl acetate 0.4780.4370.807; 11-octadecenoic acid, methyl ester; 2 -hexadecen 3,7,11,15-tetramethyl[R-[R*, R*-(E)]]-0.5490.4170.736; 14-pentadecenoic acid; cis-9-hexadecenal; ethyl oleate; heptadecanoic acid, ethyl ester; hexadecanoic acid, 1-(hydroxymethyl)1,2-ethaned iyl ester; di-(9-octadecenoyl)glycerol; hexadecanoic acid, 2-hydroxy-1(hydroxymethyl) ethyl ester; 1,2-benzene dicarboxylic acid, mono (2-ethylhexyl) ester; 9-tetradecenal, (Z)-; octadecanoic acid, 2-hydroxy-1-(hydroxymethyl) ethyl ester; squalene; behenic alcohol; and solanesol. Based on chemical analysis, two major components were contained in large quantities, i.e., n-hexadecanoic acid (31.58\%) and cis-9 hexadecenal (18.23\%). By contrast, Moustafa et al. (2016) found that the main chemical compounds of $Z$. spina-christi leaf extract are n-hexadecanoic acid, tetradecanoic acid, and cis-vaccenic acid, and Abu-Raghif et al. (2017) identified considerable amounts of $n$-hexadecanoic acid and the flavonoid 4H-pyran-4-one, 2,3-dihydro-3,5-dihydroxy-6-methyl-.
These different results are likely due to differences in the growing environment (Inbathamizh \& Padmini, 2013). However, these studies have something in common. They contain n-hexadecanoic acid in the chemical composition of Sidr leaf, and n-hexadecanoic acid has antioxidant, anticancer, and antiinflammatory properties (Aparna et al., 2012; Mazumder et al., 2020).

The chemical compounds in the Sidr leaf extract can act as antibacterial agents. The mechanism for inhibiting microbial growth involves the destruction of the bacterial cytoplasm cell membrane's integrity and triggering intracellular leakage (Bouyahya et al., 2019). This phenomenon is achieved by accumulating hydrophobic groups on phospholipids, causing cell death (Huang et al., 2019; Kinnunen et al., 2012). Phenolic components can inhibit cell DNA and RNA synthesis (Ulanowska et al., 2006). Additionally, the terpenoid group can damage cell membrane efficacy and interfere with microbial growth (Wu et al., 2016). The most significant antibacterial compound detected in the Sidr leaf extract was cis-9 hexadecenal (31.58\%). Pyrrolidine, neophytadiene, farnesyl acetate, and squalene were also detected. Cis-9 hexadecenal is a family of agrochemicals used to prevent and eradicate pests (MensahAgyei et al., 2020). Pyrrolidine is an alkaloid class compound known to function as an antifungal and antibacterial agent (Thawabteh et al., 2019). Neophytadiene and farnesyl acetate are members of the terpenoid group. Neophytadiene is an 
antimicrobial, antioxidant, antipyretic, and anti-inflammatory agent (Swamy et al., 2017). Neophytadiene, together with sitosterol components, can inhibit the growth of Vibrio parahaemolyticus (Raman et al., 2012).

Meanwhile, farnesyl acetate is a volatile component that can inhibit the growth of Gram-positive bacteria, namely, Staphylococcus aureus, Staphylococcus epidermidis, and Micrococcus luteus (Boussaada et al., 2008). Squalene, a steroid class member, detected in the Sidr leaf extract, is also an antioxidant and antibacterial agent that can inhibit Pseuduomonas aeruginosa (Awang-Jamil et al., 2021).

The fatty acids detected in the Sidr leaf extract were saturated fatty acids (25.39\%) consisting of hexadecenoic acid and octadecanoic acid, whereas the unsaturated fatty acids (11.63\%) included ethyl oleic and 11-octadecanoic acids. Fatty acids can also have antimicrobial activity. Fatty acids with an atomic $\mathrm{C}$ length less than or equal to 6 can inhibit the growth of Gramnegative bacteria (Yoon et al., 2018). Fatty acids with $\mathrm{C}$ atoms between 10 and 12 can inhibit yeast growth, whereas those with a $\mathrm{C}$ atomic length of more than 12 can inhibit the growth of Gram-positive bacteria (Potocki et al., 2021; Yoon et al., 2018). Additionally, oleic fatty acid acts as a bactericidal against the development of mycobacteria and $S$. aureus (Orhan et al., 2011). Stearic acid and palmitic acid also have an inhibitory effect but are not as significant as oleic acid (Ababutain et al., 2019).

PASS analysis was applied to understand further the potential antimicrobial role of the compounds mentioned above in combating bacterial pathogens in aquaculture (Table 3 ).

Table 3

PASS analysis of compounds identified in Sidr leaf (Ziziphus spina-christi) extract

\begin{tabular}{ccccc}
\hline \multirow{2}{*}{ No. } & Compound & Amount & \multicolumn{2}{c}{ Antibacterial } \\
\cline { 4 - 5 } & & $(\%)$ & $\mathrm{Pa}$ & $\mathrm{Pi}$ \\
\hline 1 & 1-butanol, 3-methyl- & 0.23 & 0.298 & 0.061 \\
2 & Pyrrolidine & 1.79 & 0.379 & 0.003 \\
3 & (OD) ethanol & 0.56 & $\mathrm{ND}$ & $\mathrm{ND}$ \\
4 & N-methoxy formamide & 0.37 & 0.424 & 0.025 \\
5 & 1,3,3-trimethyl-2-oxabicyclo [2.2.2 ] & 1.50 & 0.470 & 0.019 \\
& octane-6,7-endo, endo-diol & & & \\
6 & 1,3,3-trimethyl-2-oxabicyclo [2.2.2] & 0.84 & 0.470 & 0.019 \\
& octane-6,7-endo, endo-diol & & & \\
7 & Methanamine, N- [3-methyl-2- & 0.46 & 0.372 & 0.037 \\
8 & butenylidene] & & 0.363 & 0.040 \\
\hline
\end{tabular}


Table 3 (Continued)

\begin{tabular}{|c|c|c|c|c|}
\hline \multirow{2}{*}{ No. } & \multirow{2}{*}{ Compound } & \multirow{2}{*}{$\begin{array}{l}\text { Amount } \\
(\%)\end{array}$} & \multicolumn{2}{|c|}{ Antibacterial } \\
\hline & & & $\mathrm{Pa}$ & $\mathrm{Pi}$ \\
\hline 9 & 3,7,11,15-tetramethyl-2-hexadecen-1-ol & 0.30 & 0.417 & 0.026 \\
\hline 10 & Hexadecanoic acid, methyl ester & 0.42 & 0.263 & 0.076 \\
\hline 11 & n-hexadecanoic acid & 0.45 & 0.300 & 0.060 \\
\hline 12 & n-hexadecanoic acid & 1.45 & 0.300 & 0.060 \\
\hline 13 & n-hexadecanoic acid & 18.23 & 0.300 & 0.060 \\
\hline 14 & Acid & 3.98 & 0.186 & 0.022 \\
\hline 15 & Farnesyl acetate 0.4780 .4370 .807 & 0.36 & 0.437 & 0.023 \\
\hline 16 & 11-octadecenoic acid, methyl ester & 0.29 & 0.298 & 0.061 \\
\hline 17 & $\begin{array}{l}\text { 2-hexadecen 3,7,11, 15-tetramethyl- [R- [R } \\
\quad *, \mathrm{R} * \text { - (E)]] - 0.5490.4170.736 }\end{array}$ & 5.10 & 0.417 & 0.026 \\
\hline 18 & 14-pentadecenoicacid & 1.29 & 0.356 & 0.042 \\
\hline 19 & cis-9-hexadecenal & 31.58 & 0.400 & 0.030 \\
\hline 20 & Ethyl oleate & 11.34 & 0.270 & 0.073 \\
\hline 21 & Heptadecanoic acid, ethyl ester & 1.34 & 0.186 & 0.022 \\
\hline 22 & $\begin{array}{l}\text { Hexadecanoic acid, } 1 \text { - (hydroxymethyl) } \\
\text {-1.2-ethaned iyl ester }\end{array}$ & 0.33 & 0.277 & 0.069 \\
\hline 23 & Di- (9-octadecenoyl)-glycerol & 0.46 & 0.340 & 0.046 \\
\hline 24 & $\begin{array}{l}\text { Hexadecanoic acid, 2-hydroxy-1- } \\
\text { (hydroxymethyl) ethyl ester }\end{array}$ & 3.01 & 0.295 & 0.062 \\
\hline 25 & $\begin{array}{l}\text { 1,2-benzenedicarboxylic acid, mono } \\
\text { (2-ethylhexyl) ester }\end{array}$ & 0.32 & 0.309 & 0.057 \\
\hline 26 & 9-tetradecenal, (Z) - & 4.67 & 0.400 & 0.030 \\
\hline 27 & $\begin{array}{l}\text { Octadecanoic acid, 2- hydroxy-1- } \\
\text { (hydroxymethyl) ethyl ester }\end{array}$ & 0.86 & 0.295 & 0.062 \\
\hline 28 & Squalene & 5.20 & 0.295 & 0.062 \\
\hline 29 & Behenic alcohol & 1.86 & 0.225 & 0.008 \\
\hline 30 & Solanesol & 0.61 & 0.424 & 0.025 \\
\hline
\end{tabular}

Note. $\mathrm{Pa}=$ Probability to be active $; \mathrm{Pi}=$ Probability to be inactive 
Fifteen compounds (64.51\% levels) with a probability to be active $(\mathrm{Pa})$ value of more than 0.300 were found, indicating that they possess antibacterial activity. The bioactive compounds detected were as follows: 1,3,3-trimethyl-2-oxabicyclo [2.2.2] octane-6,7-endo, endo-diol ( $\mathrm{Pa}$ : $0.470)$; farnesyl acetate 0.4780 .4370 .807 (Pa: 0.437); N-methoxy formamide (Pa: 0.424); and solanesol (Pa: 0.424). Interestingly, cis-9-hexadecenal (palmitic acid), a main chemical compound in Sidr leaf, also has antimicrobial activity $(\mathrm{Pa}$ : 0.400). Previously, Kumar and Rajakumar (2016) found cis-9-hexadecenal to have anti-inflammatory, nematicide, pesticide, lubricant, antiandrogenic, flavor, hemolytic 5-alpha reductase inhibitor, antioxidant, and hypocholesterolemic properties.

Pseudo-peptide pyrrolidinedione natural products, namely moiramide $B$ and andrimid, represent a new class of antibiotics that target bacterial fatty acid biosynthesis (Pohlmann et al., 2005). $\mathrm{N}$-methyl formamide isolated from the red algae Portieria hornemannii (Lyngbye) P.C.Silva is effective against two plant pathogenic bacteria (Sivakumar et al., 2017). Additionally, Chen et al. (2007) showed that solanesol has significant inhibitory effects against E. coli, Mycobacterium phlei, $P$. aeruginosa, and $S$. aureus but poor inhibitory effects against Bacillus circulans and Bacillus subtilis. The PASS forecasting tool was used to estimate Pa:Pi (active, inactive ratio) at the forecast thresholds of $\mathrm{Pa}>30 \%$, $\mathrm{Pa}>50 \%$, and $\mathrm{Pa}>70 \%$ according to Parasuraman (2011). The forecast's average accuracy was approximately $95 \%$ based on the leave-out cross-validation calculation. The PASS forecast accuracy depends on detailed knowledge of the spectrum of biological activity for each compound available in the PASS training package. Thus, the estimation of biological activity is precise (Filimonov et al., 2014).

\section{Inhibition Test of Sidr Leaf Extract against Several Aquaculture Pathogenic Bacteria}

In vitro testing showed that the Sidr leaf extract can be used to control several aquaculture-based pathogenic bacteria. Table 4 and Figure 3 show that the Sidr leaf extract at a concentration of 500 ppm was almost as effective as tetracycline, especially for A. hydrophila, A. sobria, S. agalactiae, and $V$. parahaemolyticus. By contrast, the extract was less effective at controlling $A$. caviae, $P$. aeruginosa, and $V$. vulnificus.

Table 4

Average inhibition zone size caused by Sidr leaf (Ziziphus spina-christi) extract when exposed to pathogenic bacteria found in aquaculture settings

\begin{tabular}{lccccc}
\hline \multirow{2}{*}{ Pathogenic bacteria } & \multicolumn{5}{c}{ Average inhibition zone $(\mathrm{mm})$} \\
\cline { 2 - 6 } & $\begin{array}{c}\text { Tetracycline } \\
(\mathrm{mg} / \mathrm{L})\end{array}$ & $\begin{array}{c}100 \\
(\mathrm{mg} / \mathrm{L})\end{array}$ & $\begin{array}{c}300 \\
(\mathrm{mg} / \mathrm{L})\end{array}$ & $\begin{array}{c}500 \\
(\mathrm{mg} / \mathrm{L})\end{array}$ & $\begin{array}{c}800 \\
(\mathrm{mg} / \mathrm{L})\end{array}$ \\
\hline Aeromonas hydrophila & 15.20 & 2.87 & 9.50 & 13.17 & 6.87 \\
\hline
\end{tabular}


Table 4 (Continued)

\begin{tabular}{lccccc}
\hline \multirow{2}{*}{ Pathogenic bacteria } & \multicolumn{5}{c}{ Average inhibition zone $(\mathrm{mm})$} \\
\cline { 2 - 6 } & $\begin{array}{c}\text { Tetracycline } \\
(\mathrm{mg} / \mathrm{L})\end{array}$ & $\begin{array}{c}100 \\
(\mathrm{mg} / \mathrm{L})\end{array}$ & $\begin{array}{c}300 \\
(\mathrm{mg} / \mathrm{L})\end{array}$ & $\begin{array}{c}500 \\
(\mathrm{mg} / \mathrm{L})\end{array}$ & $\begin{array}{c}800 \\
(\mathrm{mg} / \mathrm{L})\end{array}$ \\
\hline Aeromonas caviae & 8.67 & 6.57 & 6.20 & 4.50 & 6.20 \\
Aeromonas sobria & 5.40 & 13.90 & 10.43 & 12.67 & 4.53 \\
Pseudomonas putida & 15.17 & 4.83 & 5.87 & 9.23 & 9.33 \\
Pseudomonas aeruginosa & 12.10 & 4.83 & 5.87 & 5.80 & 6.07 \\
Streptococcus agalactiae & 8.73 & 11.00 & 10.97 & 8.47 & 7.90 \\
Vibrio vulnificus & 12.70 & 2.87 & 3.80 & 2.50 & 0.00 \\
Vibrio harveyi & 18.67 & 12.20 & 9.23 & 0.00 & 3.43 \\
Vibrio parahaemolyticus & 13.00 & 3.40 & 7.23 & 12.37 & 6.17 \\
Vibrio alginolyticus & 12.03 & 10.67 & 6.93 & 3.83 & 00.00 \\
\hline
\end{tabular}

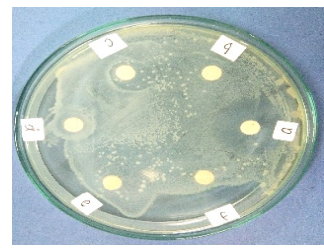

a

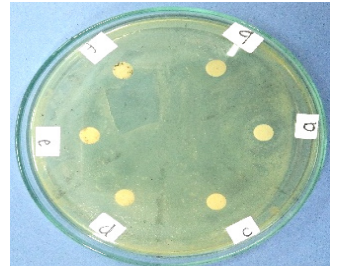

e

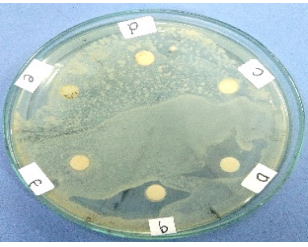

b

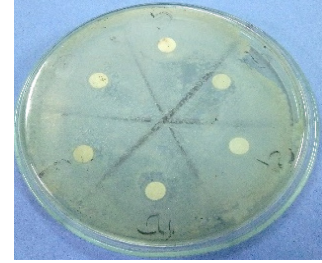

$\mathrm{f}$

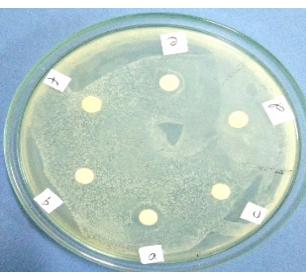

i

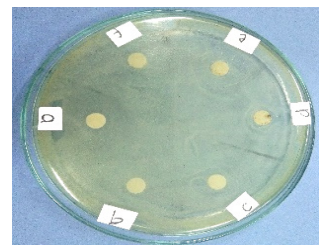

c

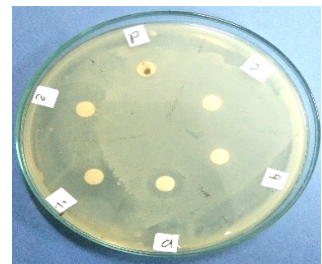

g

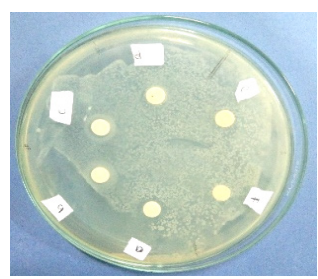

j

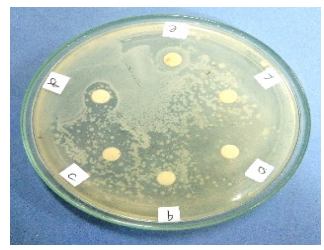

d

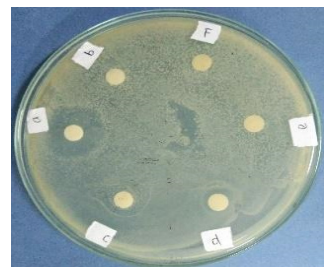

$\mathrm{h}$

Figure 3. Visual examples of the inhibition zone caused by the Sidr leaf (Ziziphus spina-christi) extract when exposed to pathogenic bacteria from aquaculture settings

Note. a) Aeromonas hydrophila, b) Aeromonas caviae, c) Aeromonas sobria, d) Aeromonas putida,

e) Pseudomonas aeruginosa, f) Streptococcus agalactiae, g) Vibrio vulnificus, h) Vibrio harveyi, i) Vibrio parahaemolyticus, and j) Vibrio alginolyticus 
Based on the in vitro results, the Sidr leaf extract can inhibit the growth of 10 pathogenic bacteria, with the degree of inhibition ranging from moderate to strong, except for $V$. vulnificus (Table 4 and Figure $3)$. The 10 bacteria tested were pathogenic to farmed fish and shrimp. Aeromonas are pathogenic bacteria that cause diseases in freshwater fish, such as common carp (Baba et al., 2016), catfish (Sarjito et al., 2018a), tilapias, eel, and goldfish (Algammal et al., 2020). Meanwhile, members of Vibrio cause a common disease among groupers, such as marine fish (Sarjito et al., 2009), mud crabs (Sarjito et al., 2018b), shrimp (Novriadi, 2016; Sarjito et al., 2018c), and cultured shellfish (Novriadi, 2016). In addition, these pathogenic bacteria can be transmitted to humans through fresh seafood (Praja \& Safnurbaiti, 2018).

For inhibition tests, the potency of inhibition is indicated by the zone diameter (strong: 10-20 mm, moderate: 5-10 mm, and weak: less than $5 \mathrm{~mm}$ ) (Pargaputri et al., 2016). The zone diameter observed from the Sidr leaf extract strongly showed inhibition of $V$. parahaemolyticus and Aeromonas bacteria at a dose of $500 \mathrm{mg} / \mathrm{L}$, except for $A$. caviae. Similarly, the Sidr leaf extract strongly inhibited vibrios ( $V$. harveyi and $V$. alginolyticus), $A$. sobria, and $S$. agalactiae at $100 \mathrm{mg} / \mathrm{L}$. The Sidr leaf extract produced weak and moderate inhibitions for $V$. vulnificus and $P$. aeruginosa, respectively. Therefore, the inhibition test results indicated that the Sidr leaf extract could be used as a natural antibiotic in fish cultivation.
The antibacterial properties of the Sidr leaf extract are consistent with a previous research report that methanolic extracts from Apocynaceae and Lamiaceae moderately inhibit $A$. hydrophila with an inhibition zone of $9.67 \mathrm{~mm}$ (Haniffa \& Kavitha, 2012). Additionally, Sidr leaf extract is antibacterial agent that is both bacteriostatic, i.e., able to inhibit the growth of bacteria, and bactericidal, i.e., able to kill bacteria (Abdel-Fatah et al., 2016; Mulyani et al., 2021). For example, Motamedi et al. (2014) showed that Sidr leaf extract is effective against $S$. aureus with the same value of minimum inhibition concentration (MIC) and minimum bactericidal concentration (MBC) of $8 \mathrm{mg} / \mathrm{mL}$. Al-Mutairi et al. (2016) reported that Sidr leaf extract could inhibit the growth of $P$. aeruginosa with a MIC of $100 \mathrm{mg} / \mathrm{L}$. Mulyani et al. (2021) demonstrated that MIC and MBC of Sidr leaf extract impede $E$. coli with a zone diameter of $11.1 \mathrm{~mm}$ were at $50 \%$ and $75 \%$, respectively. Moreover, Brito et al. (2015) demonstrated that Sidr leaf extract could inhibit several antibiotic-resistant bacterial strains and acts against rhabdomyosarcoma cells (Abu-Raghif et al., 2017). Table 2 shows that the lowest concentration of Sidr leaf extract used in the present study $(100 \mathrm{mg} / \mathrm{L})$ could inhibit tested aquatic pathogenic bacteria. Based on these data, it seems likely that Sidr extract is potentially a natural antibiotic in aquaculture. The results in this study are in line with those of Alhassan et al. (2019), Al-Mutairi et al. (2016), Khaleel et al. (2019), and Temerk et al. (2017). The results indicate 
that the Sidr leaf extract has the potential as an antibacterial agent. Thus, Sidr leaf extract should be tested as an alternative antibacterial agent to inhibit pathogenic bacterial growth in aquaculture.

\section{CONCLUSION}

The Sidr leaf extract contains phytochemicals, namely, flavonoids, alkaloids, saponins, tannins, and steroids, with antibacterial properties. GC-MS analysis showed that the Sidr leaf extract has 30 compounds that function as an antiseborrheic. These compounds include the following: 1-butanol, 3-methyl; (OD) ethanol; pyrrolidine; n-methoxy formamide; two molecules of 1,3,3-trimethyl-2-oxabicyclo [2.2.2] octane6,7-endo, endo-diol; methenamine, n-[3methyl-2-butenylidene]; neophytadiene; 3,7,11,15-tetramethyl-2-hexadecen-1-ol; hexadecanoic acid, methyl ester; three kinds of n-hexadecanoic acid; acid; farnesyl acetate 0.4780 .4370 .807 ; 11-octadecenoic acid, methyl ester; 2-hexadecen-3,7,11, 15 - t e t r a m e th y 1 - [ R - [ R *, R * (E)]]-0.5490.4170.736; 14-pentadecenoic acid; cis-9-hexadecenal; cis-9-hexadecenal; ethyl oleate; heptadecanoic acid, ethyl ester; hexadecanoic acid, 1-(hydroxymethyl)1,2-ethanediyl ester; di-(9-octadecenoyl)glycerol; hexadecanoic acid, 2-hydroxy-1(hydroxymethyl) ethyl ester; 1,2 benzene dicarboxylic acid, mono (2-ethylhexyl) ester; 9-tetradecenal, (Z); octadecanoic acid, 2-hydroxy-1-(hydroxymethyl) ethyl ester; squalene; behenic alcohol; and solanesol. PASS analysis demonstrated 15 compounds (64.51\% level) having antibacterial activity and a $\mathrm{Pa}$ value of more than 0.300 . The inhibition test demonstrated that the Sidr leaf extract exhibits moderate-to-strong inhibition to aquaculture pathogenic bacteria, except for $V$. vulnificus, which produced a weak inhibition. These results indicate that the Sidr leaf extract can be used as a natural herb to control bacterial pathogens in fish cultivation.

\section{ACKNOWLEDGMENTS}

The authors thank the Dean of Faculty of Fisheries and Marine Science of Diponegoro University for financial support (91/ UN7.5.10.2/PP/2021). The authors also thank Dr. Lestari Lakshmi Widowati, the Head of the Aquaculture Laboratory at the Faculty of Fisheries and Marine Science, Diponegoro University, for facilities support.

\section{REFERENCES}

Ababutain, I. M. (2019). Antimicrobial activity and gas chromatography-mass spectrometry (GC-MS) analysis of Saudi Arabian Ocimum basilicum leaves extracts. Journal of Pure and Applied Microbiology, 13(2), 823-833. https:// doi.org/10.22207/JPAM.13.2.17

Abdel-Fatah, M. A., Hussein, N. H., Hawash, S. I., \& Shaarawy, H. H. (2016). Investigation of using Sidr leave extracts in nano-silver preparation. ARPN Journal of Engineering and Applied Sciences, 11(19), 11649-11654.

Abu-raghif, A. R., Jasim, G. A., \& Hanoon, M. M. (2017). Anti-proliferative activity of Zizyphus spina-christi leaves methanol extract against rhabdomyosarcoma (RD) cell line. International Journal of Pharmacy and Pharmaceutical Sciences, 9(2), 279-282. https:// doi.org/10.22159/ijpps.2017v9i2.15013 
Adamczak, A., Ożarowski, M., \& Karpiński, T. M. (2020). Antibacterial activity of some flavonoids and organic acids widely distributed in plants. Journal of Clinical Medicine, 9(1), 109. https:// doi.org/10.3390/jcm9010109

Ads, E. N., Rajendrasozhan, S., Hassan, S. I., Sharawy, S. M. S., \& Humaidi, J. R. (2017). Phytochemical, antimicrobial and cytotoxic evaluation of Ziziphus spina-christi (L.) stem bark. Biomedical Research, 28(15), 6646-6653.

Algammal, A. M., Mohamed, M. F., Tawfiek, B. A., Hozzein, W. N., Kazzaz, W. M. E., \& Mabrok, M. (2020). Molecular typing, antibiogram and PCRRFLP based detection of Aeromonas hydrophila complex isolated from Oreochromis niloticus. Pathogens, 9(3), 238. https://doi.org/10.3390/ pathogens 9030238

Alhassan, K. A., Indabawa, A. S., \& Shah, M. M. (2019). Phytochemical analysis, proximate composition and antibacterial activities of Ziziphus species (Z. jujube and Z. spina christi). Journal of Applied and Advanced Research, 4(1), 42-46. https://doi.org/10.21839/jaar.2019. v4i1.262

Al-Mutairi, M. H., Ali, S., Aly, S. M., \& Aldebasi, Y. (2016). Antibacterial activity of Sidr (Ziziphus spina-christi), leaves extract against selected pathogenic bacteria. European Journal of Pharmaceutical and Medical Research, 3(5), 138-144.

Aparna, V., Dileep, K. V., Mandal, P. K., Karthe, P., Sadasivan, C., \& Haridas, M. (2012). Antiinflammatory property of $n$-hexadecanoic acid: Structural evidence and kinetic assessment. Chemical Biology and Drug Design, 80(3), 434-439. https://doi.org/10.1111/j.17470285.2012.01418.x

Asgarpanah, J., \& Haghighat, E. (2012). Phytochemistry and pharmacologic properties of Ziziphus spina christi (L.) Willd. African
Journal of Pharmacy and Pharmacology, 6(31), 2332-2339. https://doi.org/10.5897/ajpp12.509

Atujona, D., Cai, S., \& Amenyogbe, E. (2018). Mini review on Vibrio infection - A case study on Vibrio harveyi clade. Fisheries and Aquaculture Journal, 9(4), 1000258. https://doi. org/10.4172/2150-3508.1000258

Awang-Jamil, Z., Aminuddin, M. F., Zaidi, B. Q., Basri, A. M., Ahmad, N., \& Taha, H. (2021). Phytochemicals and antimicrobial analysis of selected medicinal plants from Brunei Darussalam. Biodiversitas, 22(2), 601-606. https://doi.org/10.13057/biodiv/d220211

Baba, E., Acar, Ü., Öntaş, C., Kesbiç, O. S., \& Yilmaz, S. (2016). The use of Avena sativa extract against Aeromonas hydrophila and its effect on growth performance, hematological and immunological parameters in common carp (Cyprinus carpio). Italian Journal of Animal Science, 15(2), 325-333. https://doi.org/10.108 0/1828051X.2016.1185977

Bentzon-Tilia, M., Sonnenschein, E. C., \& Gram, L. (2016). Monitoring and managing microbes in aquaculture - Towards a sustainable industry. Microbial Biotechnology, 9(5), 576-584. https:// doi.org/10.1111/1751-7915.12392

Boussaada, O., Ammar, S., Saidana, D., Chriaa, J., Chraif, I., Daami, M., Helal, A. N., \& Mighri, Z. (2008). Chemical composition and antimicrobial activity of volatile components from capitula and aerial parts of Rhaponticum acaule DC growing wild in Tunisia. Microbiological Research, 163(1), 87-95. https://doi.org/10.1016/j. micres.2007.02.010

Bouyahya, A., Abrini, J., Dakka, N., \& Bakri, Y. (2019). Essential oils of Origanum compactum increase membrane permeability, disturb cell membrane integrity, and suppress quorumsensing phenotype in bacteria. Journal of Pharmaceutical Analysis, 9(5), 301-311. https:// doi.org/10.1016/j.jpha.2019.03.001 
Brito, S. M. O., Coutinho, H. D. M., Talvani, A., Coronel, C., Barbosa, A. G. R., Vega, C., Figueredo, F. G., Tintino, S. R., Lima, L. F., Boligon, A. A., Athayde, M. L., \& Menezes, I. R. A. (2015). Analysis of bioactivities and chemical composition of Ziziphus joazeiro Mart. using HPLC-DAD. Food Chemistry, 186, 185-191. https://doi.org/10.1016/j.foodchem.2014.10.031

Chen, H. B., Zhang, J., Yu, H. X., \& Hu, Q. L. (2007). In vitro study on the antibacterial of a medicinal intermediate, solanesol. Qilu Pharmaceutical Affairs, 26, 558-559.

Dangoggo, S. M., Hassan, L. G., Sadiq, I. S., \& Manga, S. B. (2012). Phytochemical analysis and antibacterial screening of leaves of Diospyros mespiliformis and Ziziphus spina-christi. Chemical Engineering Journal, 1(1), 31-37.

Doğan, A., Otlu, S., Çelebİ, Ö, Aksu Kiliçle, P., Gülmez Sağlam, A., Doğan, A. N. C., \& Mutlu, N. (2017). An investigation of antibacterial effects of steroids. Turkish Journal of Veterinary and Animal Sciences, 41(2), 302-305. https://doi. org/10.3906/vet-1510-24

Ermias, R., Tukue, M. \& Bahlbi, A. (2011). Phytochemical screening of Ziziphus spinachristi and Piper nigrum. Journal of Atoms and Molecules, 1(1), 41-47.

Filimonov, D. A., Lagunin, A. A., Gloriozova, T. A., Rudik, A. V., Druzhilovskii, D. S., Pogodin, P. V., \& Poroikov, V. V. (2014). Prediction of the biological activity spectra of organic compounds using the pass online web resource. Chemistry of Heterocyclic Compounds, 50(3), 444-457. https://doi.org/10.1007/s10593-014-1496-1

Gull, J., Sultana, B., Anwar, F., Naseer, R., Ashraf, M., \& Ashrafuzzaman, M. (2012). Variation in antioxidant attributes at three ripening stages of guava (Psidium guajava L.) fruit from different geographical regions of Pakistan. Molecules, 17(3), 3165-3180. https://doi.org/10.3390/ molecules 17033165
Haniffa, M. A., \& Kavitha, K. (2012). Antibacterial activity of medicinal herbs against the fish pathogen Aeromonas hydrophila. Journal of Agricultural Technology, 8(1), 205-211.

Huang, F., Kong, J., Ju, J., Zhang, Y., Guo, Y., Cheng, Y., Qian, H., Xie, Y., \& Yao, W. (2019). Membrane damage mechanism contributes to inhibition of trans-cinnamaldehyde on Penicillium italicum using Surface-Enhanced Raman Spectroscopy (SERS). Scientific Reports, 9(1), 490. https://doi.org/10.1038/s41598-01836989-7

Ibrahim, J. A., Egharevba, H. O., Nnamdi, R. A., \& Kunle, O. F. (2015). Comparative pharmacognostic and phytochemical analysis of Ziziphus spina-christi (L.) Desf. and Ziziphus abyssinica Hochst. ex A. Rich. International Journal of Pharmacognosy and Phytochemical Research, 7(6), 1160-1166.

Igbinosa, I. H., Beshiru, A., \& Igbinosa, E. O. (2017). Antibiotic resistance profile of Pseudomonas aeruginosa isolated from aquaculture and abattoir environments in urban communities. Asian Pacific Journal of Tropical Disease, 7(1), 47-52. https://doi.org/10.12980/apjtd.7.2017D6-363

Inbathamizh, L., \& Padmini, E. (2013). Effect of geographical properties on the phytochemical composition and antioxidant potential of Moringa oleifera flowers. BioMed Research International, 1(3), 239-247.

Joshua, W. J., \& Zulperi, Z. (2020). Effects of Spirulina platensis and Chlorella vulgaris on the immune system and reproduction of fish. Pertanika Journal of Tropical Agricultural Science, 43(4), 429-444. https://doi.org/10.47836/pjtas.43.4.01

Khaleel, S. M., Jaran, A. S., \& Al-Deeb, T. M. F. (2019). Antimicrobial and lipid peroxidation inhibition potential of Ziziphus spina-christi (Sedr), a Jordanian medicinal plant. Journal of Biological Sciences, 19(2), 131-136. https://doi. org/10.3923/jbs.2019.131.136 
Kinnunen, P. K., Kaarniranta, K., \& Mahalka, A. K. (2012). Protein-oxidized phospholipid interactions in cellular signaling for cell death: From biophysics to clinical correlations. Biochimica et Biophysica Acta-Biomembranes, 1818(10), 2446-2455. https://doi.org/10.1016/j. bbamem.2012.04.008

Kumar, D. G., \& Rajakumar R. (2016). Gas chromatography mass spectrometry analysis of bioactive components from the ethanol extract of Avicennia marina leaves. Innovare Journal of Science, 4(4), 9-12.

Mazumder, K., Nabila, A., Aktar, A., \& Farahnaky, A. (2020). Bioactive variability and in vitro and in vivo antioxidant activity of unprocessed and processed flour of nine cultivars of Australian lupin species: A comprehensive substantiation. Antioxidants, 9(4), 282. https://doi.org/10.3390/ antiox 9040282

Mbunde, M., Mdegela, R. H., Laswai, H. S., \& Mabiki, F. P. (2018). Quantification of phenolics, flavonoids and antioxidant activity of Tamarindus indica from selected areas in Tanzania. Biofarmasi Journal of Natural Product Biochemistry, 16(1), 22-28. https://doi. org/10.13057/biofar/f160103

Mensah-Agyei, G. O., Ayeni, K. I., \& Ezeamagu, C. O. (2020). GC-MS analysis of bioactive compounds and evaluation of antimicrobial activity of the extracts of Daedalea elegans: A Nigerian mushroom. African Journal of Microbiology Research, 14(6), 204-210. https:// doi.org/10.5897/ajmr2019.9120

Monteiro, S. H., Andrade, G. M., Garcia, F., \& Pilarski, F. (2018). Antibiotic residues and resistant bacteria in aquaculture. The Pharmaceutical and Chemical Journal, 5(4), 127-147.

Motamedi, H., Seyyednejad, S. M., Hasannejad, Z., \& Fariba Dehghani, F. (2014). A comparative study on the effects of Ziziphus spina-christi alcoholic extracts on growth and structural integrity of bacterial pathogens. Iranian Journal of Pharmaceutical Sciences, 10(2), 1- 10.

Moustafa, M. F., Hesham, A. E. L., Quraishi, M. S., \& Alrumman, S. A. (2016). Variations in genetic and chemical constituents of Ziziphus spinachristi L. populations grown at various altitudinal zonation up to $2227 \mathrm{~m}$ height. Journal of Genetic Engineering and Biotechnology, 14(2), 349-362. https://doi.org/10.1016/j.jgeb.2016.09.001

Mulyani, S., Adriani, M., \& Wirjatmadi, B. (2021). Antibacterial activity of extract ethanol bidara leaves (Ziziphus spina-christi L.) on Enteropathogenic coli. Indian Journal of Forensic Medicine and Toxicology, 15(1), 1589-1595. https://doi.org/10.37506/ijfmt. v15i1.13638

Novriadi, R. (2016). Vibriosis in aquaculture. OmniAkuatika, 12(1), 24. https://doi.org/10.20884/1. oa.2016.12.1.24

Orhan, I., Özçelik, B., \& Şener, B. (2011). Evaluation of antibacterial, antifungal, antiviral, and antioxidant potentials of some edible oils and their fatty acid profiles. Turkish Journal of Biology, 35(2), 251-258. https://doi.org/10.3906/ biy-0907-107

Pan, C. Y., Tsai, T. Y., Su, B. C., Hui, C. F., \& Chen, J. Y. (2017). Study of the antimicrobial activity of tilapia piscidin 3 (TP3) and TP4 and their effects on immune functions in hybrid tilapia (Oreochromis spp.). PLOS One, 12(1), e0169678. https://doi.org/10.1371/journal. pone. 0169678

Parasuraman, S. (2011). Prediction of activity spectra for substances. Journal of Pharmacology and Pharmacotherapeutics, 2(1), 52-53. https://doi. org/10.4103/0976-500X.77119

Pargaputri, A. F., Munadziroh, E., \& Indrawati, R. (2016). Antibacterial effects of Pluchea indica Less. leaf extract on E. faecalis and Fusobacterium nucleatum (in vitro). Dental Journal, 49(2), 93-98. https://doi.org/10.20473/j. djmkg.v49.i2.p93-98 
Pohlmann, J., Lampe, T., Shimada, M., Nell, P. G., Pernerstorfer, J., Svenstrup, N., Brunner, N. A., Schiffer, G., \& Freiberg, C. (2005). Pyrrolidinedione derivatives as antibacterial agents with a novel mode of action. Bioorganic and Medicinal Chemistry Letters, 15(4), 11891192. https:/doi.org/10.1016/j.bmcl.2004.12.002

Potocki, L., Oklejewicz, B., Kuna, E, Szpyrka, E., Duda, M., \& Zuczek, J. (2021). Application of green algal Planktochlorella nurekis biomasses to modulate growth of selected microbial species. Molecules, 26(13), 4038. https://doi.org/10.3390/ molecules26134038

Prabu, E., Felix, S., Felix, N., Ahilan, B., \& Ruby, P. (2017). An overview on significance of fish nutrition in aquaculture industry. International Journal of Fisheries and Aquatic Studies, 5(6), 349-355.

Praja, R. K., \& Safnurbaiti, D. P. (2018). The infection of Vibrio parahaemolythicus in shrimp and human. Oceana Biomedicina Journal, 1(1), 44-58. http://doi.org/10.30649/obj.v1i1.6

Raman, V., Samuel, L., Saradhi, P., Rao, N., Krishna, N. V., Sudhakar, M., \& Radhakrishnan, T. (2012). Antibacterial, antioxidant activity and GC-MS analysis of Eupatorium odoratum. Asian Journal of Pharmaceutical and Clinical Research, 5(2), 99-106.

Ravi, L., Manasvi V., \& Praveena Lakshmi, B. (2016). Antibacterial and antioxidant activity of saponin from Abutilon indicum leaves. Asian Journal of Pharmaceutical and Clinical Research, 9(3), 344-347. https://doi.org/10.22159/ajpcr.2016. v9s3.15064

Riyadi, P. H., Romadhon R., Anggo A. D., Herawati V. E., \& Setyastuti A. I. (2020). PASS and ADMET analyses for eight compounds from Nile tilapia (Oreochromis niloticus) viscera waste hydrolysate as anti-inflammatory nutraceutical. AACL Bioflux, 13(5), 2630-2638.
Sarjito, Haditomo, A. H. C., Desrina, Ariyati R. W., \& Prayitno, S. B. (2018a). The diversity of causative agent associated with bacterial diseases on catfish (Clarias gariepinus) with molecular based from Demak, Indonesia. Omni-Akuatika, 14(2), 100-106.

Sarjito, Haditomo, A. H. C., Desrina, Djunaedi, A., \& Prayitno, S. B. (2018b). The bacterial diversity associated with bacterial diseases on mud crab (Scylla serrata Fab.) from Pemalang Coast, Indonesia. In Journal of Physics: Conference Series (Vol. 1025, No. 1, p. 012076). IOP Publishing. https:/doi.org/10.1088/17426596/1025/1/012076

Sarjito, Radjasa O. K, Prayitno, S. B., \& Hutabarat, S. (2009). Phylogenetic diversity of the causative agents of vibriosis associated with groupers fish from Karimunjawa Islands, Indonesia. Current Research in Bacteriology, 2(1), 14-21. https:// doi.org/10.3923/crb.2009.14.21

Sarjito, Haditomo, A. H. C, Desrina, Djunaedi, A., \& Prayitno S. B. (2018c). The diversity of vibrios associated with vibriosis in pacific white shrimp (Litopenaeus vannamei) from extensive shrimp pond in Kendal District, Indonesia. In $I O P$ Conference Series: Earth and Environmental Science (Vol. 116, No. 1, p. 012011). IOP Publishing. https://doi.org/10.1088/17551315/116/1/012011

Sivakumar, S. R., Radhakrishnan, S., \& Kulangiappar, K. (2017). Isolation of N-methyl formamide from red algae Portieria hornemannii (Lyngbye) P.C. Silva active against two plant pathogenic bacteria. American-Eurasian Journal of Agricultural and Environmental Sciences, 17(1), 99-106.

Soni, H. \& Malik, J.K. (2021). Phyto-pharmacological potential of Zizyphus jujube: A review. Scholars International Journal of Biochemistry, 4(2), 1-5. https://doi.org/10.36348/sijb.2021.v04i01.001

Statistics Indonesia. (2020). Produksi perikanan budidaya menurut provinsi dan jenis budidaya, 
2000-2018 [Aquaculture production by province and type of cultivation, 2000-2018]. https://www. bps.go.id/statictable/2009/10/05/1706/produksiperikanan-budidaya-menurut-provinsi-dan-jenisbudidaya-2000-2017.html

Stein, S. E., Mikaia, A., White, E., Zaikin, V., Zhu, D., Sparkman, O. D., Neta, P., \& Zenkevich, I. (2014). NIST Standard Reference Database 1A. https:// www.nist.gov/document/nistlaver22manpdf

Suliman, M. B., \& Mohammed, A. A. (2018). Preliminary phytochemical screening and antibacterial activity of ethanolic and aqueous extracts of Sudanese medicinal plant Ziziphus spina-christi L. leaves. Arabian Journal of Medicinal and Aromatic Plants, 4(1), 35-44.

Swamy, M. K., Arumugam, G., Kaur, R., Ghasemzadeh, A., Yusoff, M. M., \& Sinniah, U. R. (2017). GCMS based metabolite profiling, antioxidant and antimicrobial properties of different solvent extracts of Malaysian Plectranthus amboinicus leaves. Evidence-Based Complementary and Alternative Medicine, 2017, 1517683. https:// doi.org/10.1155/2017/1517683

Taghipour, M. T., Nameni, R., Taghipour, M., \& Ghorat, F. (2020). Phytochemical analysis and antimicrobial activity of Ziziphus spinachristi and Tamarix aphylla leaves' extracts as effective treatment for Coronavirus Disease 2019 (COVID-19). Thrita, 9(2), e107776. https://doi. org/10.5812/thrita. 107776

Temerk, H. A., Salem, W. M., Sayed, W. F., \& Hassan, F. S. (2017). Antibacterial effect of phytochemial extracts from Ziziphus spina-christi against some pathogenic bacteria. Egyptian Journal of Botany, 57(3), 595-604. https://doi.org/10.21608/ ejbo.2017.665.1035
Thawabteh, A., Juma, S., Bader, M., Karaman, D., Scrano, L., Bufo, S. A., \& Karaman, R. (2019). The biological activity of natural alkaloids against herbivores, cancerous cells and pathogens. Toxins, 11(11), 656. https://doi. org/10.3390/toxins 11110656

Tran, N., Rodriguez, U. P., Chan, C. Y., Phillips, M. J., Mohan, C. V., Henriksson, P. J. G., Koeshendrajana, S., Suri, S., \& Hall, S. (2017). Indonesian aquaculture futures: An analysis of fish supply and demand in Indonesia to 2030 and role of aquaculture using the AsiaFish model. Marine Policy, 79, 25-32. https://doi. org/10.1016/j.marpol.2017.02.002

Ulanowska, K., Tkaczyk, A., Konopa, G., \& Węgrzyn, G. (2006). Differential antibacterial activity of genistein arising from global inhibition of DNA, RNA and protein synthesis in some bacterial strains. Archives of Microbiology, 184(5), 271278. https://doi.org/10.1007/s00203-005-0063-7

Wu, Y., Bai, J., Zhong, K., Huang, Y., Qi, H., Jiang, Y., \& Gao, H. (2016). Antibacterial activity and membrane-disruptive mechanism of 3-p-transcoumaroyl-2-hydroxyquinic acid, a novel phenolic compound from pine needles of Cedrus deodara, against Staphylococcus aureus. Molecules, 21(8), 1084. https://doi.org/10.3390/ molecules 21081084

Yoon, B. K., Jackman, J. A., Valle-Gonzalez, E. R., \& Cho, N. J. (2018). Antibacterial free fatty acids and monoglycerides: Biological activities, experimental testing, and therapeutic applications. International Journal of Molecular Sciences, 19(4), 1114. https://doi.org/10.3390/ ijms19041114 